\title{
Quantification and Graphic Representation of EFL Textbook Evaluation Results
}

\author{
Mohammad Reza Ghorbani \\ Bojnord University, Iran \\ Email: mrg872@yahoo.com
}

\begin{abstract}
Part of the English language problems in Iran are supposed to arise from the inadequacies in the design of the prescribed English textbooks used at high school levels. This study examines the first grade English textbook used in Iran's senior high schools based on the current research findings in syllabus design, English language teaching, and the specific language teaching situation in Iran to determine the extent to which it conforms to the common universal characteristics of EFL/ESL textbooks. Detailed analysis focused specifically on the use of a checklist extracted from different EFL textbook evaluation checklists corresponding to the local needs. The findings show that only $63 \%$ percent of the book conforms to the universal characteristics of textbooks. It is hoped that policy makers, textbook writers, and teachers strive to effectively match textbooks with the needs of the learners.
\end{abstract}

Index Terms-EFL textbook, evaluation, graphic presentation, checklist, instruction

\section{INTRODUCTION}

Although the significance of the textbook as a universal component of English language teaching is undeniable (Hutchison and Torres 1994), it is difficult to define the textbook role in the language classroom perfectly and exactly. Textbooks provide teachers and students with a common framework. However, it is not enough to use them, from cover to cover, for meeting students' needs. It is necessary for instructors to strike a balance between being a slave to their texts and providing organized, objective-based instruction (Garinger, 2002). To do so, instructors need updated criteria to evaluation system to use as

Evaluation, as an underlying element in the development of innovations and modifications within the educational context, is a dynamic process which investigates the suitability and appropriateness of an existing practice (Rea-Dickens and Germaine 1992) and can be used as a useful device for both teachers and material writers. However, despite its undeniable role in improving various aspects of teaching programs, evaluation is not still a well supported part of a project (Hargreaves, 1989).

Many experts suggest that evaluation checklists should be used for a thorough examination of a textbook's language content. For example, Cunningsworth (1984) deals with the necessity of relating materials to course objectives and the learner's needs. Sheldon's (1988) checklist focuses on assessing all aspects of content ranging from graphics and physical characteristics to authenticity and flexibility. Ansary and Babaii (2002) believe that although these approaches are the most common and likely straightforward, the shaky theoretical basis of such checklists and the subjectivity of judgments have often been a source of disappointment. Perhaps, that is why the relative merits of such checklists and their criteria, over the years, would diminish and new checklists would be needed. They suggest a scheme, which is based on a selected set of common consensus-reached and some theory-neutral, universal characteristics of EFL/ESL textbooks, for a systematic textbook evaluation.

The textbook evaluation criteria developed by the researcher for this study is based on a set of universal (but not theory-neutral) characteristics which not only correspond to the local needs, but also are flexible enough to be used worldwide with some modifications. Before proceeding to the main research topic, a description of Iranian educational system, English education and grading system at senior high schools is provided in the following text to help the reader understand the research context.

\section{A. English Education in Iran}

In Iran, English is taught as a foreign language and is practiced within a context-restricted environment, in which the textbook and classroom teacher play the main role. The difference between English as a foreign language (EFL) and English as a second language (ESL) is that in an ESL context, English is taught as a partial or general medium of instruction for other subjects, while in an EFL context, instruction in other subjects is not usually in English (Prator, 1991).

Previously, English education in Iran formally started from second grade in junior high schools, but now it begins from the first grade. All schools at different levels follow the curriculum standards. The ME compiles, develops and publishes textbooks and teaching materials for nationwide public and private high schools (Eslami-Rasekh \& Valizadeh, 2008, 2004). 
According to the senior high school regulations prescribed by the ME in Iran, the average instruction time is three hours per week for the first grade, two hours for the second grade, and two hours per week for the third grade in senior high schools. English education, particularly at the pre-university level, has been focusing on reading skill. Most pre-university and senior high school English teachers, therefore, have been using the grammar translation teaching method in their classrooms (Hosseini, 2007).

Students' translation abilities have improved because the medium of instruction is Persian. They can translate materials written in English into Persian but they cannot use the language communicatively. The reforms of the ME, especially in the areas of curriculum development and teaching materials to the language education, do not seem to have been successful so far.

Due to a technological revolution and scientific advancements, the curriculum in pre-university and senior high school English education has been called into question and revised several times. The current textbooks for senior high school and pre-university English education were developed to put more emphasis on communicative competence, but they are far from being called communicative textbooks.

According to Hosseini (2007), even nowadays many teachers use the grammar translation method and the textbooks lack listening and speaking activities. Furthermore, the writing activities are confined to grammatical exercises such as making passive sentences, putting the scrambled words and phrases in order, etc.

\section{B. Statement of the Problem}

Students usually study the English language for seven years in Iranian high schools and pre-university centers. Although most of them master the related prescribed textbooks and pass their examinations with relatively good marks, very few of them leave the system with the ability to speak English effectively or use it communicatively. Famous Iranian Language testing and teaching specialists such as Farhady, Jafarpoor, and Birjandi (1994) have already confirmed that even Iranian students at the university level are not able to use the English language for communicative purposes as they are expected to.

Almost all Iranian English teachers are aware of the fact that the instruction of spoken English in the public and private school system faces major problems. Many English conversation institutes and language teaching centers out of the formal educational system throughout the country are in operation. They owe their existence to the very weakness of spoken English instruction in the formal education system.

Since many students encounter immense problems in terms of using the English language communicatively after graduating from senior high schools and pre-university centers, one might ask where the origin of these problems is. They may arise from different sources and have various reasons. However, it is assumed that the predicament is mainly caused by the inadequacies in English teachers' instruction and curriculum planning (Jahangard, 2007).

As most students encounter immense English language problems after graduating from high school, one might ask where these problems arise from. This study suggests that the predicament is mainly caused by the inadequacies in the design of the prescribed English textbooks used at junior and senior high school levels. Thus, this study is designed to investigate the extent to which the EFL textbooks in Iranian senior high schools conform to the common consensus-reached and universal characteristics of EFL/ESL textbooks.

\section{Significance of the Study}

The primary importance of dealing with language education problems is reflected in the obligatory law in which the teaching of English as a foreign language (EFL) must be included in the general syllabus of all Iranian schools. Despite the fact that textbooks are an important element in most of EFL classes, there has been little investigation in terms of how and why materials are selected by teachers. The reason for this may lie in the fact that in the age of communicative teaching, experts who advise on the use of textbooks may seem out of step with current language teaching methodology. Yet, regardless of how great an emphasis is placed on the use of authentic materials, teachers frequently do not have the time and the administrative support to collect and adapt all the necessary materials for their classes. Therefore, researchers are required to provide more guidance to enable teachers and administrators to make wiser decisions.

According to Tomlinson (1996), the process of materials evaluation can be seen as a means of carrying out action research. In doing so, this study first seeks to evaluate the Iranian high school EFL textbook (English 1) based on current trends in ELT, curriculum design, and materials development to find out whether they conform to the universal characteristics of EFL textbooks and recent pedagogical principles. And then, it highlights the main shortcomings of the textbook and offer suggestions to improve both the structure of English course and the design of the textbooks.

The current English Textbooks (English 1, 2 and 3), which are taught at the Iranian senior high schools, do not conform to the developments resulting from applied linguistic debates of the last two decades. The books have not been properly revised since they were introduced. Moreover, neither at the stage of introducing these textbooks, nor at any other stage, was any need analysis survey carried out. Therefore, there is an urgent need for evaluating and possibly updating the materials according to recent findings in applied linguistics and curriculum design. But it should be remembered that the implications of evaluation in a nation-wide educational context of public schools are of crucial sensitivity and consequences. Hence, it is necessary to choose and define the relevant criteria by which the merits and drawbacks of the textbooks are going to be examined.

The textbook evaluation criteria developed by the researcher for this study are based on a set of universal 
characteristics of EFL textbooks which not only correspond to the local needs, but also are flexible enough to be used worldwide. The developed checklist was used and the content of the book was analyzed to evaluate the textbook.

By using a checklist, this study had a potential to explore and explain the weaknesses and strengths of the textbook which will be helpful for materials writers, curriculum designers, researchers, Curriculum Development Center of the Ministry of Education and teachers.

\section{Research Question}

In order to facilitate the investigation regarding the evaluation of the EFL textbook (English 1) used in Iranian senior high schools, the researcher formulated the following research question.

To what extent does the EFL textbook (English 1) used in Iranian senior high schools conform to the common consensus-reached and universal characteristics of EFL/ESL textbooks?

\section{REVIEW OF LITERATURE}

According to Prabhu (1987), textbooks ensure uniformity and accountability. They are both realizations and determinants of methods (Vassilakis 1997). In Iran, English language textbooks are pivotal to the language teaching program because they are the sole source of language input for the students who need to master English language for their future use. Since all decisions regarding curriculum, materials and instruction are determined by the Curriculum Development Center of the Ministry of Education, teachers are expected to strictly follow the guidelines created for them by the national government. Therefore, textbooks need to be continuously evaluated based on updated criteria.

There are many factors to be taken into account when evaluating material for use with EFL students. According to Nunan (1988) materials are an essential part of the curriculum. Chambers (1997), Harmer (1998), and Garinger (2002) offer a number of criteria to consider when analyzing textbooks for EFL/ESL classes. Cunningsworth (1984) deals with the necessity of relating materials to course objectives and the learner's needs. Sheldon's (1988) checklist focuses on assessing all aspects of content ranging from graphics and physical characteristics to authenticity and flexibility. Though these approaches are more common and straightforward, other writers go beyond simply content and instead focus on cognitive and affective factors.

Skierso (1991) and Chall and Conard (1991) employed Bloom's Taxonomy of the Cognitive Domain to assess textbooks. According to Umer Azim (2005), Chall and Conard use Bloom's Taxonomy and a "Question Complexity Rating Scale" to evaluate textbook activities. These improvements and amendments refer to a paradigm shift to the process of learning versus the product of learning which implies focusing only on outcomes may not always address all the EFL learner's needs.

According to Riazi and Mosalanejad (2010), the textbook evaluation studies in Iran have focused on developing textbook evaluation criteria (Ansary \& Babaii, 2002) or investigating strengths and weaknesses of the present textbooks (Jahangard, 2007; Riazi \& Aryashokouh, 2007). This study used most of those criteria to examine the shortcomings of the current English textbook (English 1).

Ansary and Babaii (2002) believe that teachers, students, and administers are all consumers of textbooks. They may have conflicting views about what a good textbook is. However, the question is where they can turn to for reliable advice on how to make an informed decision and select a suitable textbook. The literature on textbook selection and evaluation procedure is vast. There have been various suggestions by different scholars for teachers (Chastain, 1971; Tucker, 1975; Candlin \& Breen, 1979; Daoud \& Celce-Murcia, 1979; Williams, 1983; Hutchinson and Waters, 1987; Sheldon, 1988; Skierso, 1991; Ur, 1996; Littlejohn, 1996). Checklists offered by them are usually based on supposedly generalizable criteria and a variety of methods to assess a particular textbook under scrutiny.

According to Ansary and Babaii (2002), the fundamental problem with such checklists is their dependence on the swings of the theoretical pendulum (Sheldon, 1988). For example, Tucker (1975, p. 357) proposes "adequacy of pattern practice" and Penny Ur (1996, p. 186) offers "good grammar practice" as two criteria which may not be rated now the same as a decade or so ago. In addition, these checklists neglect some important criteria like "competence of the author" (Tucker, 1978, p.358) and "whether or not a textbook is based on the findings of a contrastive analysis of English and L1 sound systems" (William, 1983, p. 255). If one's own priorities and specific requirements are not identified and taken into account in a specific teaching situation, it would be difficult to rely on any already-available checklist criteria to judge teaching materials. That is why such checklists and their criteria lose their significance over the years and new ones are required. Ansary and Babaii (2002) argue that no neat formula can provide a definite way to judge a textbook. They therefore compiled a list of what they deem to be a set of theory-neutral and universal features of EFL/ESL textbooks.

Collectively, these evaluation lists may or may not include the issues or elements that reflect the concerns of teachers using textbooks. Therefore, selecting particular items to create a personal evaluation index is the best method for ensuring that the realities of each individual learning situation are addressed. Some of those criteria are used in the newly developed checklist by the researcher.

\section{MEthodology}


Through a comprehensive review of the relevant literature and by taking into consideration the English teaching/learning context in Iran, the researcher seeks to establish the prime criteria by which different aspects of the current EFL textbook English Book 1 will be analyzed and evaluated.

\section{A. Materials}

One of the current English Language Teaching textbooks English Book 1 (Birjandi, Soheili, Noruzi and Mahmodi 2006) that is locally designed to cater for and respond to the English language needs of Iranian students in grade one at senior high schools was taken to serve as the corpus of present study. It was content analyzed in terms of the criteria in the checklist under 7 subheadings: A. Practical Consideration, B. Skills, C. Exercises and Activities, D. Pedagogic Analysis, E. Appropriacy, F Supplementary Materials, and G. General Impression.

\section{B. Instrumentation}

A large number of EFL classes around the world today are using textbooks which were not chosen by the careful application of objective evaluation criteria. One effective way to ensure that the needs and wants of learners are given careful consideration when choosing textbooks is to apply a written checklist of appropriate selection criteria to potential textbooks. Such a checklist if used must be tailored to the needs and wants of the learners who will use the textbook.

It is necessary to use checklists designed for the local situation. Sheldon (1988, p. 241) states that "textbook criteria are emphatically local". A universally appropriate textbook could hardly exist, and neither could a universally appropriate list of textbook evaluation criteria.

Following Ansary and Babaii's (2002) suggestion, in an attempt to locate some universal and broad characteristics of EFL/ESL textbooks and to draw up, as such, some guidelines for the generation and systematic evaluation of EFL/ESL textbooks, the researcher reviewed many EFL/ESL textbooks and EFL/ESL textbook evaluation checklists. Then, an attempt was made to discover important elements in EFL/ESL textbooks. Then, a selected set of common consensus-reached (but not theory-neutral) characteristics of EFL/ESL textbooks was identified. And finally, they were tailored to the needs and wants of the learners.

\section{Creation of the Checklist}

Decisions related to textbook selection will affect teachers, students, and the overall classroom dynamic. It is probably one of the most important decisions facing EFL educators. The use of an evaluation procedure or checklist can lead to a more systematic and thorough examination of potential textbooks and to enhanced outcomes for learners, instructors, and administrators.

So a new checklist was created to evaluate the EFL textbook (English 1) being used in Iranian senior high schools. To produce this checklist, several factors were considered. Firstly, the previously published lists were examined and their most salient features considered. Areas of commonality between them are reflected in the new list. Secondly, there was an attempt to balance both the practical and theoretical concerns involved in choosing the criteria.

The designed checklist takes elements from the suggestions and checklists of Matthews (1985, p. 206), D. Williams (1983, p. 255),R. Williams (1981, p. 159), Daoud \& Celce-Murcia (1979), Hutchinson and Waters (1987), Cunningsworth (1984, p. 75-79), Breen and Candlin(1987, p. 13-28), Sheldon (1988, p. 242-245), Tucker, C. A. (1975), Ur, P. (1996), Skierso, 1991, Littlejohn, 1996, Chambers (1997), Harmer (1998), Garinger (2002) and Ansary and Babaii (2002) and adapts them, with the addition of new items and a new scoring system. It is on the basis of the needs and wants of the learners.

\section{Data Collection and Analysis Procedures}

The newly developed checklist (See Appendix A) was used to collect as many types of data as possible. This checklist was designed to produce a score for the textbook evaluated. Scores are not explained in absolute terms but can be used for comparison if more than one textbook is evaluated. There are 50 items on the checklist, with 2 points possible for each item. The criteria are numerically rated on a scale from 0 to 2 in the blank space of the score column as follows:

$$
\begin{aligned}
& 2=\text { Good } \\
& 1=\text { Satisfactory } \\
& 0=\text { Poor }
\end{aligned}
$$

What follows is a demonstration of how the checklist system works. Evaluation essentially involved the following steps based on the procedures Ansary and Babaii (2002) followed and the analyses they did in their research. First, an evaluation checklist with two columns was designed. The universal features of EFL/ESL textbooks tailored and adapted to the needs of the learners appeared in the first column on the form. A merit score consisting of numbers 0 to 2 appeared in the second column on the checklist. A comparative weight is assigned to the relative realization of each actual criterion in the textbook under scrutiny: a perfect match between the ideal defined criterion and its actual realization in the textbook receiving 2 , a total lack a score of 0 , and any inadequate match a score of 1.

Finally, the numbers in the merit score column after each criterion were represented on a graph by drawing (1) a dotted line corresponding to the numerical value of the Merit Scores, and (2) a straight solid line to represent the perfect 
scores (see appendix B).

Ansary and Babaii (2002) argue that this framework has a dual utility. On the one hand, if the evaluations of several raters should be compared and contrasted in order to reach a correlated consensus, several opinions of a single textbook can be easily displayed on the same graph. On the other hand, an evaluator can display his judgments about several textbooks on a single graph using a separate line for each textbook. In this way, he may compare the profiles of various textbooks, see them in contrast to the ideal solid line, and judge how far a particular textbook can satisfy his requirements. If this is done, not only are the differences among various textbooks portrayed, but also any instances of marked variation can be noted and revised.

\section{FINDINGS}

In an attempt to analyze descriptively the English Book 1 for the grade-one students of senior high schools in Iran, the research found the strengths and weaknesses of the textbook with a hope to help teachers, students, guardians and related administrators make a judgment on EFL textbook selection and use. The procedure of data collection and analysis went simultaneously and the texts were explored thoroughly with a particular focus on the checklist criteria under 7 subheadings: A. Practical Considerations, B. Skills, C. Exercises and Activities, D. Pedagogic Analysis, E. Appropriacy, F. Supplementary Materials, and G. General Impression. Although there is no universal canon according to which an EFL textbook can be evaluated. This paper made an attempt to analyze the English Book 1 based on the newly developed checklist criteria consisting of the above-mentioned 7 broad subheadings. The findings based on the checklist criteria showed 63 percent satisfaction which answers the following research question.

To what extent does the EFL textbook (English 1) used in Iranian senior high schools conform to the common consensus-reached and universal characteristics of EFL/ESL textbooks?

So, 63 percent of the evaluated textbook conforms to the common consensus-reached and universal characteristics of EFL/ESL textbooks. The findings for the 7 broad subheadings are as follows:

\section{A. Practical Considerations}

The textbook has sufficient number of pictures to make the situation more life-like, although there is a lack of color photographs and drawings in it. The paper used for the textbooks is of good quality; each sheet is quite thick and ensures durability of the texts. Binding is not so strong, but the physical appearance is interesting and attractive. Good printing not only makes a book attractive but also motivates the learners to read. Crowded printing or small fonts demotivate the students. The good printing, size and type of the fonts used in this book undoubtedly guarantee the smooth readability of the texts. The layout is clear and well-organized. The topic of each unit is written in bold type. Reading passages are of normal font size that is just right for the first graders. All the letters unanimously are in black color. There are no traces of weak points in the font size for topic and exercises, the top, bottom, left and right margins, the space between words, sentences, lines and paragraphs, the quality and color of ink used, etc. The researcher went thoroughly through the textbook but found no cases of errors. It ensures thorough editing and proofreading of the textbook. The instructions are exclusively in English which is difficult for students to understand without the teacher's help. On the whole, in terms of practical considerations the book is good.

\section{B. Skills}

The balance between listening, speaking, reading, and writing skills development in the book is not appropriate to the learners and learning situation. The textbook devote a particular space for two language skills, that is, reading and writing. Speaking is paid little attention and listening is completely neglected. Speaking activities do not make students able to speak correctly about their thoughts and feelings. The skills that are presented in the textbook do not include a wide range of cognitive listening and speaking skills that will be challenging to the learners. The skills integration and the development of discourse and fluency skills are not given sufficient attention. Most of the speaking activities are mainly based on pair work only, giving very little attention to other communicative activities like group work, simulation, role play, etc.

Most reading materials are passages which draw the content from a number of areas like science, transportation, foreign language, education, etc. Reading activities are mainly limited to question-answer types that range from simple scanning questions to questions that ask for opinions and arguments. Although the reading texts have wide coverage of topics and content, they considerably lack variety in materials and activities.

Actual writing does not exist in the book. Writing exercises and activities are just a written practice of grammatical structures and presentations. The textbook does not incorporate activities like writing experiences or a diary, writing a letter to a friend etc. There are no challenging writing tasks, for example, writing a letter to a singer by a fan, writing a message, etc. The textbook does not lead students from simple controlled writing activities to guided writing activities, and gradually expose free activities.

\section{Exercises and Activities}

Students are supposed to become familiarized with the basic characteristics of English sounds such as stress, intonation and pauses, and pronounce English sounds correctly. There are a number of phonological gaps between 
English and Persian. Persian, for example, lacks English sounds like w, th, and a number of vowels. These phonological gaps are neglected to be emphasized.

Selection and gradation of vocabulary items are not mainly on the basis of simplicity and frequency of occurrence. There is a list of vocabulary items tagged at the end of each textbook, and presented alphabetically. These words are not accompanied with their phonetic transcription in English and their Persian or English meanings are not given in the glossary. Also there are not sufficient number of exercises meant for practicing vocabulary items attempting to develop the ability, for example, to guess the meaning of unknown words, or to find synonyms or to find antonyms. Such activities can be incorporated through vocabulary games, word puzzles, and vocabulary quizzes.

Nowadays no EFL textbook likes to be purely grammatical in terms of selection and gradation of language materials. The authors of this book also seem to realize that the focus should be on developing communicative competence of the students rather than grammatical competence. There is a sufficient treatment of grammar in this textbook. The writing exercises are also grammatical structures rather than writing practices.

Language functions are purposes for which people use language, eg. greeting, apologizing, complaining, describing, etc. Functions should combine appropriate grammatical structures used in particular situations with purposes. Although the overall objective of the course is to develop students' basic communication abilities, there is not sufficient focus on the language functions and appropriate activities. The dialogs do not appear to be communicative.

\section{Pedagogic Analysis}

The overall aim of teaching English in senior high school is to make students communicatively competent. But the presentation of grammar and communication skills is not in a well balanced manner. However, knowingly or unknowingly, the textbook is more structural than communicative. The book is not methodologically in line with current worldwide theories and practices of language learning. It does not contain any formal learner achievement tests. It is not sufficiently challenging to the learners and it is not enabling the learners to use English outside the classroom situation.

\section{E. Appropriacy}

The materials, instructions, language focus and activities in general are less appropriate for the learners. The material does not facilitate interactive learning. Vocabulary and comprehensible input levels are not well-graded. The material is age-appropriate but does not match the learner objectives.

\section{F. Supplementary Materials}

The textbooks are not accompanied with audio CDs for listening. In fact there are no listening activities such as 'listen and write', 'listen and choose', 'listen and fill out', etc. No teacher's guide book or student's workbook is available to give useful guidance, along with alternative activities. The teacher's guide book was offered for the first and the last time when the first edition of the book was published and prescribed in the 1990s.

\section{G. General Impression}

The book doesn't include reasonable balance \& range in skills and activities. It doesn't motivate learners by pleasurable activities. It doesn't encourage learners to assume responsibility for their own learning. It doesn't provide a variety of Communicative activities to promote the use of information/opinion gap. Learners can not use English unless they do really use it. Communicative activities are those activities with which students develop an ability to use language for communicative purposes. No attempt has been made to lead students toward a situation where they can use maximum English. A lot of room could have been used to make activities more communicative with information gap, allowing variety in presentation of tasks and activities. It can be a better idea, as most EFL/ESL textbooks do, to make a gradual shift from students' native language to target language as they go in higher grades. Also the instructions can appear bilingually for lower grades.

\section{CONCLUSION}

The textbook is perfect in physical qualities like paper quality, binding, printing, etc. But a good attempt has not been made to present four language skills in a well balanced manner. There are no audio CDs and student guides as reference materials. And teacher's guide is not available. It would have been a better idea if the writers had made an attempt to introduce pronunciation and listening activities accompanied with CDs.

The book doesn't have glossary at the end and is more structural than communicative. It seriously lacks variety in the communicative tasks and information gap activities. Most of the speaking activities are mainly based on questionanswer type activities and pair work only, giving very little attention to other communicative activities like group work, simulation, role play, etc. Efforts can be made to present different kinds of speaking activities in a more balanced way and more diversified form, allowing more information gaps in the tasks. Apart from question- answer type activities tagged at the end of a reading passage, reading activities can be made more interesting adding variety like fill in the blanks, matching two halves, etc.

Though there are five elements in language instruction, and learners should be the center of instruction. However, materials often control the instruction, since teachers and learners tend to rely heavily on them. Materials which are appropriate for a particular class need to have an underlying instructional philosophy, approach, method and technique 
which suit the students and their needs. They should have correct, natural, current and standard English.

Through this textbook analysis, it is hoped that language professionals will gain some knowledge on how to perform this procedure for themselves. Implications suggest that textbook developers, by using appropriate checklists can include more universal characteristics in their EFL/ESL textbooks which, at the same time, are tailored and adapted to the needs of the learners. Textbooks that appear sound on the surface often lack many of the criteria of a truly superior book. Therefore, it is necessary for individuals who are making these choices to carefully examine all aspects of the text and compare it against an assessment tool. An evaluation checklist, whether adopted from another author or created by the researcher, serves to focus this examination and ensures that significant factors will not be missed.

This process is going to continue to be demanding as publishers provide more and more options to teachers, although in some countries like Iran textbooks are dictated by the Ministry of Education and teachers cannot have any choice. With the growth of computer-assisted language learning, the role of the textbook may be changing, but it is unlikely that it will ever disappear. Therefore, it is necessary for teachers to be well-equipped with the skills to evaluate materials to ensure that students are using the highest quality texts possible and that their language learning experience is enhanced, not hindered, by the books used in their classrooms.

63 percent satisfaction of the only textbook which is prescribed and used for the first grade students in Iranian high schools nationwide can hardly be considered as acceptable and satisfactory. Therefore, it is important that all individuals involved at all levels of programme, from policy makers to administrators, material designers, curriculum developers, textbook writers, and teachers, consider the importance of their decisions and make wise judgment at right time, and strive to effectively match textbooks with the identified needs of the learners.

\section{APPENDIX A TeXTbOOK EVALUATION ChECKLIST}

This checklist is designed for evaluating EFL textbooks used in Iranian Senior High Schools.

Name of evaluator: Mohammad Reza Ghorbani

Title of the textbook: English Book 1

Publisher: The General Bureau for Textbooks Printing and Distribution (Iranian Ministry of Education)

Date of publication: 2007

Stated level of learners: First grade in senior high school

Cost of student's book: 1700 Rials

\begin{tabular}{|c|c|}
\hline Criteria for EFL textbook evaluation & Merit Score \\
\hline \multicolumn{2}{|l|}{ A. Practical Considerations } \\
\hline 1. Is it available locally? & 2 \\
\hline 2. Is it cost-effective? & 2 \\
\hline 3. Is the physical appearance interesting and attractive? & 2 \\
\hline 4. Is there an appropriate mix of graphics and text? & 2 \\
\hline 5. Is the layout clear and Well-organized? & 2 \\
\hline 6. Are the headings effectively used? & 2 \\
\hline 7. Is it appropriate for local situation? & 1 \\
\hline 8. Does it have an appropriate size, weight and title? & 2 \\
\hline \multicolumn{2}{|l|}{ B. Skills } \\
\hline 9. Are the skills presented in the textbook appropriate to the course? & 1 \\
\hline 10. Does the textbook provide learners with adequate guidance as they are acquiring these skills? & 1 \\
\hline $\begin{array}{l}\text { 11. Do the skills that are presented in the textbook include a wide range of cognitive skills that will be challenging to } \\
\text { learners? }\end{array}$ & 1 \\
\hline $\begin{array}{l}\text { 12. Is the balance between listening, speaking, reading, and writing skills development in the book appropriate to the } \\
\text { particular learners and learning situation? }\end{array}$ & 1 \\
\hline 13. Is the skills integration given sufficient attention? & 1 \\
\hline 14. Is the development of discourse and fluency skills given sufficient attention? & 1 \\
\hline C. Exercises and Activities & 1 \\
\hline 15. Do the exercises and activities in the textbook promote learners' language development? & 1 \\
\hline 16. Is there a balance between controlled and free exercises? & 1 \\
\hline $\begin{array}{l}\text { 17. Do the exercises and activities reinforce what students have already learned and represent a progression from } \\
\text { simple to more complex? }\end{array}$ & 2 \\
\hline 18. Are the exercises and activities varied in format so that they will continually motivate and challenge learners? & 2 \\
\hline 19. Are there activities for communicative interaction and the development of communicative strategies? & 1 \\
\hline 20. Are new structures presented systematically and in a meaningful context? & 2 \\
\hline 21. Is the meaning of new vocabulary presented in context? & 2 \\
\hline 22. Is there sufficient work on recognition and production of individual sounds for pronunciation practice? & 1 \\
\hline 23. Is there sufficient work on recognition and production of stress patterns and intonation? & 1 \\
\hline 24. Is there a summary of new and reviewed grammar? & 1 \\
\hline 25. In general are the activities in the book neither too difficult nor too easy for the learners? & 2 \\
\hline \multicolumn{2}{|l|}{ D. Pedagogic Analysis } \\
\hline 26. Is the book methodologically in line with current worldwide theories and practices of language learning? & 1 \\
\hline 27. Does the book contain adequate formal learner achievement tests? & 0 \\
\hline 28. Is the book enabling learners to use English outside the classroom situation? & 1 \\
\hline 29. Is the book sufficiently challenging to learners? & 1 \\
\hline
\end{tabular}




\begin{tabular}{|l|l|}
\hline 30. Are there mechanisms for giving regular feedback to learners? & 1 \\
\hline 31. Are new items reviewed and recycled throughout the book? & 1 \\
\hline $\begin{array}{l}\text { 32. Does the book match the syllabus of the school to a sufficient extent? } \\
\text { Is the time allowance indicated appropriate? }\end{array}$ & 2 \\
\hline E. Appropriacy & \\
\hline 33. Are the materials, instructions, language focus and activities in general appropriate for the learners? & 1 \\
\hline 34. Will the textbook meet the long and short term goals specific to the learners? & 1 \\
\hline 35. Does the material match learner objectives? & 1 \\
\hline 36. Does the material facilitate interactive learning? & 1 \\
\hline 37. Is the material socio-culturally appropriate? & 2 \\
\hline 38. Is the material up-to-date? & 2 \\
\hline 39. Are vocabulary and comprehensible input levels well-graded? & 1 \\
\hline 40. Is the material age-appropriate? & 2 \\
\hline 41. Is the material relevant to real life? & 2 \\
\hline F. Supplementary Materials & \\
\hline 42. Is a teacher's book available and does it give useful and complete guidance, along with alternative activities? & 0 \\
\hline 43. Is a workbook available and does it contain appropriate supplementary activities? & 0 \\
\hline 44. Are audio-visual aids accompanied? And are they of good quality? & 0 \\
\hline G. General Impression & \\
\hline 45. Does it have clear objectives \& instructions? & 1 \\
\hline 46. Does it include reasonable balance \& range in skills and activities? & 1 \\
\hline 47. Does it motivate learners by pleasurable activities or arouse learner interest? & 1 \\
\hline 48. Does it provide a variety of Communicative activities? Does it promote the use of information/opinion gap? & 1 \\
\hline 49. Is the cultural tone of the book overall appropriate for use in the setting? & 2 \\
\hline 50. Does the book encourage learners to assume responsibility for their own learning? & 1 \\
\hline Total & 63 \\
\hline
\end{tabular}

EVALUATION RESULT: 63\% SATISFACTION

APPENDIX B

GRAPHIC REPRESENTATION OF THE EVALUATION

\begin{tabular}{|c|c|c|c|}
\hline Poor $=0$ & Satisfactory $=1$ & Good $=2$ & Merit Score \\
\hline & & & 2 \\
\hline & & & 2 \\
\hline & & & 2 \\
\hline & & & 2 \\
\hline & & & 2 \\
\hline & & & 2 \\
\hline & & & 1 \\
\hline & & & 2 \\
\hline & & & 1 \\
\hline & & & 1 \\
\hline & & & 1 \\
\hline & & & 1 \\
\hline & & & 1 \\
\hline & & & 1 \\
\hline & & & 1 \\
\hline & & & 1 \\
\hline & & & 2 \\
\hline & & & 1 \\
\hline & & & 1 \\
\hline & & & 2 \\
\hline & & & 2 \\
\hline & & & 1 \\
\hline & & & 1 \\
\hline & & & 1 \\
\hline & & & 2 \\
\hline & & & 1 \\
\hline & & & 0 \\
\hline & & & 1 \\
\hline & & & 1 \\
\hline & & & 1 \\
\hline & & & 1 \\
\hline & & & 2 \\
\hline & & & 1 \\
\hline & & & 1 \\
\hline
\end{tabular}




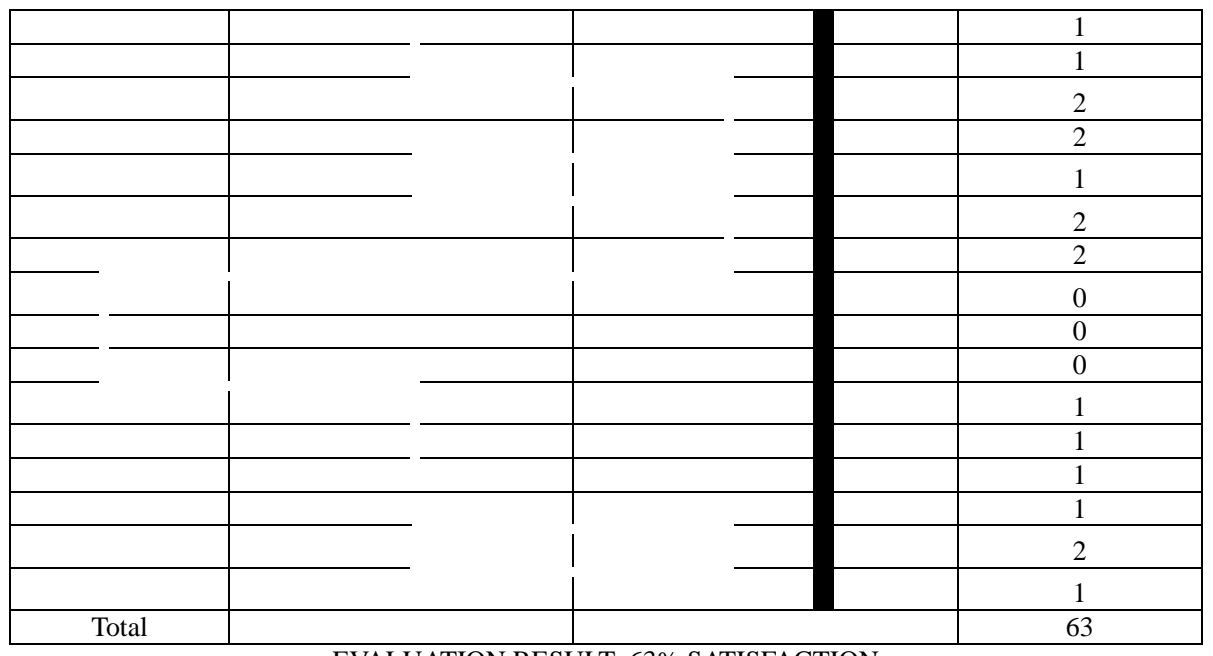

EVALUATION RESULT: 63\% SATISFACTION

Note: Developed by Ansary and Babaii (2002). From Internet TESL Journal @ 2002. Used with permission.

\section{REFERENCES}

[1] Aliakbari, Mohammad (2002). Culture in ELT programs: An evaluation of the issue of culture in the Iranian ELT program in high school level. Unpublished doctoral dissertation. The University of Isfahan.

[2] Ansary, H. \& Babaii, E. (2002). Universal characteristics of EFL/ESL textbooks: A step towards systematic textbook evaluation The Internet TESL Journal, 8(2), available on-line at: http:/iteslj.org/Ansary-textbooks/

[3] Bardovi-Harlig, K., Hartford, B.A.S., Mahan-Taylor, R., Morgan, M. J., \& Reynolds, D. W. (1991). Developing pragmatic awareness: Closing the conversation. ELT Journal, 45, 4-15.

[4] Berry, R. (2000). "You-ser" friendly metalanguage: What effect does it have on learners of English? International Review of Applied Linguistics in Language Teaching, 38, 195-211.

[5] Boxer, D., \& Pickering, L. (1995). Problems in the presentation of speech acts in ELT materials: The case of complaints. ELT Journal, 49, 44-58.

[6] Burns, A. (1998). Teaching speaking. Annual Review of Applied Linguistics, 18, 102-123.

[7] Cane, G. (1998). Teaching conversation skills more effectively. The Korea TESOL Journal, 1, 31-37. [-16-]

[8] Candlin, C.N. \& Breen, M.P. (1979). Evaluating, adapting and innovating language teaching materials. In C. Yorio, K. Perkins and J. Schacter (Eds.) On TESOL '79: The learner in focus (pp. 86-108). Washington, D.C.: Teachers of English to Speakers of Other Languages.

[9] Chambers, F. (1997). Seeking Consensus in Coursebook Evaluation. ELT Journal, 51(1), 29-35.

[10] Chastain, K. (1971). The development of modern language skills: Theory to practice (pp. 376-384). Philadelphia. The Center for Curriculum Development, Inc.

[11] Cunningsworth, A. (1984). Evaluating and selecting EFL teaching materials. London: Heinemann Educational Books.

[12] Daoud, A. \& Celce-Murcia, M. (1979). Selecting and evaluating a textbook. In M. Celce-Murcia and L. McIntosh (Eds.), Teaching English as a second or foreign language (pp. 302-307). Cambridge, MA: Newbury House Publishers.

[13] Eslami-Rasekh, Z. \& Valizadeh, K. (2004). Classroom activities viewed from different perspectives: Learners' voice vs. teachers' voice. TESL EJ, 8(3), 1-13. Retrieved October 9, 2008, from http://tesl-ej.org/ej31/a2.html

[14] Eslami-Rasekh, Z. \& Valizadeh, K. (2008). Teachers' sense of self-efficacy, English proficiency, and instructional strategies: A study of nonnative EFL teachers in Iran. TESL EJ, 11(4), 1-19. Retrieved October 9, 2008 from http://tesl-ej.org/ej44/a1.pdf

[15] Garinger, D. (2002). Textbook Selection for the ESL Classroom. Available on-line at http://www.cal.org/resources/digest/0210garinger.html

[16] Grant, L., \& Starks, D. (2001). Screening appropriate teaching materials: Closing from textbooks and television soap operas. International Review of Applied Linguistics in Language Teaching, 39, 39-50.

[17] Harmer, J. (1998). How to Teach English. Essex: Longman.

[18] Hargreaves, A. (1989). Curriculum and assessment reform. Toronto: OISE Press.

[19] Hosseini, S. M. H. (2007). ELT in higher education in Iran and India - A critical view. Language in India, 7, 1-11. Retrieved October 9, 2008, from http://www.languageinindia.com/dec2007/eltinindiaandiran.pdf

[20] Hutchinson and Torres. (1994). The textbook as agent of change. ELT J.; 48: 315-328.

[21] Hutchinson, T. \& Waters, A. (1987). English for Specific Purposes: A learning-centred approach. Cambridge: Cambridge University Press.

[22] Jahangard, A. (2007). The evaluation of the EFL materials taught at Iranian public high schools. Karen's Linguistics Issues. Retrieved from: http://www3.telus.net/linguisticsissues/bymonth.html.

[23] Jolly, D. and R. Bolitho (1998). A framework for materials writing. Materials Development in Language Teaching. B. Tomlinson. Cambridge, Cambridge University Press: 90-115.

[24] Kim, D., \& Hall, J. K. (2002). The role of an interactive book reading program in the development of second language pragmatic competence. Modern Language Journal, 86, 332-348.

[25] Littlejohn, A. (1996). The analysis of language teaching materials: Inside the Trojan Horse. In B. Tomlinson, (Ed.), Materials development in language teaching (pp. 191-213). Cambridge: Cambridge University Press. 
[26] Matthews, A. (1985). Choosing the best available textbook. In Matthews, A., Spratt, M., and Dangerfield, L. (eds.) At the chalkface. London: Edward Arnold, pp 202206.

[27] Nunan, D. (1988). The learner-centered curriculum. Cambridge: Cambridge University Press.

[28] Prabhu ,N. S 1987. Second Language Pedagogy. Oxford: Oxford University Press, pp. 94-95.

[29] Prator, C. H. (1991). Cornerstones of method and names for the profession. In M. Celce-Murcia (Ed.), Teaching English as a second or foreign language (2nd ed.). New York: Newbury House.

[30] Rea-Dickens, P. \& Germaine, K. (1992). Evaluation. Oxford: Oxford University Press.

[31] Sheldon, L. (1988). Evaluating ELT textbooks and materials. ELT Journal, 42 (4), 237-246.

[32] Riazi, A.M., \& Aryashokouh, A. (2007). Lexis in English textbooks in Iran: Analysis of exercises and proposals for consciousness-raising activities. Pacific Association of Applied Linguists, 11, 17-34.

[33] Riazi, M., and Mosalanejad, N. (2010). Evaluation of learning objectives in Iranian High-School and Pre-University English textbooks using Bloom's Taxonomy. The Electronic Journal for English as a Second Language,3(4), 1-16.

[34] Skierso, A. (1991). Textbook selection and evaluation. In M. Celce-Murcia (Ed.), Teaching English as a second or foreign language (pp. 432-453). Boston, MA: Heinle \& Heinle Publishers.

[35] Talebinezhad, M. R./Aliakbari, M. (2002). "Evaluation and Justification of a Paradigm Shift in the Current ELT Models in Iran." The Internet Linguistik online 10/1. http://www.linguistik-online.de/10_02/talebinezhadaliakbari.html

[36] Tomlinson, B. (Ed.). (1996). Materials development in language teaching. Cambridge: Cambridge University Press.

[37] Tucker, C. A. (1975). Evaluating beginning textbooks. English Teaching Forum, 13, 355-361.

[38] Umar Aziz, m. (2005). Evaluation and comparison of textbooks of ESL/EFL classroom. Unpublished M.A. Thesis. Retrieved from faculty.ksu.edu.sa/umerazim/publications/thesis.doc

[39] Ur, P. (1996). A course in language teaching: Practice \& Theory (pp. 184-187). Cambridge: Cambridge University Press.

[40] Vassilakis, G. (1997). Materials and methods: Need they be in conflict? Paper presented by at the TESOL Greece Saturday seminar on Material Choice and Development in the EFL Classroom (9th February).

[41] Williams, D. (1983). Developing criteria for textbook evaluation. ELT Journal, 37(3), 251-255.

[42] Williams, R. (1981). A procedure for ESP textbook analysis and evaluation on teacher education courses. English for Specific Purposes Journal 1/2, pp 155-162.

[43] Wong, J. (2001). "Applying" conversation analysis in applied linguistics: Evaluating dialogue in English as a second language textbooks. International Review of Applied Linguistics in Language Teaching, 40, 37-60.

Mohammad Reza Ghorbani has worked as an EFL teacher and researcher in Iran, Japan, and Malaysia since 1990. He has published two books on educational issues and eight articles in specialized international journals. He has also presented six papers in international conferences. His interests are English Teaching, Learning, Testing, and Evaluation. 